Article

\title{
Immune Response of Drosophila suzukii Larvae to Infection with the Nematobacterial Complex Steinernema carpocapsae-Xenorhabdus nematophila
}

\author{
Anna Garriga ${ }^{1}$, Maristella Mastore ${ }^{2}$, Ana Morton ${ }^{1}$, Fernando Garcia del Pino ${ }^{1, *(\mathbb{D})}$ and \\ Maurizio Francesco Brivio ${ }^{2} *$ (D) \\ 1 Departament de Biologia Animal, Biologia Vegetal i Ecologia, Facultat de Biociències, Universitat Autònoma \\ de Barcelona, Bellaterra, 08193 Barcelona, Spain; anna.garriga.oliveras@uab.cat (A.G.); \\ ana.morton@uab.cat (A.M.) \\ 2 Laboratory of Comparative Immunology and Parasitology, Department of Theoretical and Applied Sciences, \\ University of Insubria, 21100 Varese, Italy; maristella.mastore@uninsubria.it \\ * Correspondence: fernando.garcia@uab.cat (F.G.d.P.); maurizio.brivio@uninsubria.it (M.F.B.); \\ Tel.: +39-0332-421404 (M.F.B.)
}

Received: 14 February 2020; Accepted: 26 March 2020; Published: 28 March 2020

\begin{abstract}
Entomopathogenic nematodes have been proposed as biological agents for the control of Drosophila suzukii, an invasive pest of small-stone and soft-skinned fruits. Larvae of the fly are susceptible to Steinernema carpocapsae infection but the reaction of immune defenses of the host are unknown. To determine the immune response, larvae were infected with $S$. carpocapsae and Xenorhabdus nematophila to evaluate the effector mechanisms of both humoral and cellular processes. The symbiont bacteria presented an inhibitory effect on the phenoloxidase cascade with a low level of melanization. Besides, X. nematophila activated the synthesis of putative antimicrobial peptides on the hemolymph of infected larvae. However, those peptides presented a lower antimicrobial activity compared to hemolymph from larvae infected with non-symbiont bacteria. Xenorhabdus nematophila avoided also the phagocytosis response of hemocytes. During in vitro and in vivo assays, S. carpocapsae was not encapsulated by cells, unless the cuticle was damaged with a lipase-treatment. Hemocyte counts confirmed differentiation of lamellocytes in the early phase of infection despite the unrecognition of the nematodes. Both X. nematophila and S. carpocapsae avoided the cellular defenses of $D$. suzukii larvae and depressed the humoral response. These results confirmed the potential of entomopathogenic nematodes to control D. suzukii.
\end{abstract}

Keywords: Drosophila suzukii; immunity; entomopathogenic nematodes; Steinernema carpocapsae; Xenorhabdus nematophila; humoral defenses; cellular defenses

\section{Introduction}

Entomopathogenic nematodes (EPNs) belonging to families Steinernematidae and Heterorhabditidae (Nematoda: Rhabditida) are obligate parasites of a wide range of insects [1]. These nematodes have a mutualistic relationship with a bacteria of the genera Xenorhabdus and Photorhabdus respectively, that helps to kill the insect [2]. The infective juveniles (IJs) enter the host through natural body openings or by penetrating the cuticle and release the bacteria [3]. The nematode-bacteria complex kills the host within 24 to $48 \mathrm{~h}$ through septicemia or toxemia [4]. Thus, nowadays, EPNs are used as biological control agents in the management of agricultural pests [5]. An important factor that affects the efficacy of EPNs is the immune response of the insect host [6]. The cuticle of the insects is the first defense against nematodes together with an intense grooming behavior [7]. When IJs penetrate through the cuticle into the hemocoel, physiological and immune defenses are 
activated in response to nematode presence [8,9]. Recognition of non-self, mainly based on the interaction between pathogen-associated molecular patterns and pattern-recognition receptors (PAMPs and PRRs), is crucial for the proper occurrence of cellular and humoral immune responses [10,11]. In insects, PAMPs and PRRs mediate the discriminatory step before triggering humoral responses, such as proPO system or antimicrobial peptide synthesis (AMPs). The proPO system is a complex enzymatic cascade responsible for the melanization reaction. This process leads to the production of melanin that can encapsulate invaders and opsonic factors enhancing immune reactions; moreover, drosophila phenoloxidases (PO) seem to play a role also in hemolymph clotting as a further defensive mechanism aimed to prevent the entry of nematodes and microorganisms [12-14]. Unlike the proPO system, which is rather well preserved and homogeneous among arthropod species, AMPs show different structural conformations among insects and various mechanisms to kill microorganisms [15].

PRRs also activate cellular responses like phagocytosis and encapsulation; phagocytosis is a conserved process mediated by hemocytes against various small targets including bacteria and yeast $[16,17]$. Instead, encapsulation is the main defense against the presence of multicellular targets, such as nematodes or endo-parasitoids. In the Drosophila family, three main types of hemocytes or immunocompetent cells (plasmatocytes, lamellocytes, and crystal cells) are found in the hemolymph and are responsible for the immune functions described [18]. Plasmatocytes represent the most abundant hemocytes and play a crucial role in target recognition, phagocytosis activity, and as promoters of encapsulation. These cells recall and differentiate to lamellocytes [19], which are involved in the formation of multi-layered capsules. The third cell population consists of crystal cells, which contain the enzymes of the proPO cascade and quickly degranulate in the presence of non-self [20].

Nevertheless, EPNs have developed strategies to evade and suppress the insect immune defenses during all stages of infection [6]. During a nematobacterial infection, three steps can be identified: in the early phase, IJs must evade and/or depress the host immune system just after entry. Afterward, in the midterm phase, symbiont bacteria are released and secret toxic compounds that contribute to killing the host. Finally, the long phase is the reproductive stage of nematodes [21]. Nemato-bacterial strategies are based on mimicry processes [22] or active suppression of host defenses [9]. Steinernema carpocapsae (Weiser) (Rhabditida: Steinernematidae) has been reported using mimic insect recognition proteins expressed in the epicuticle of IJs that evade detection $[23,24]$. This nematode can also damage immune defenses with proteolytic secretions, modulate proPO activity, and avoid encapsulation in different insect species [25-27]. In addition, its symbiont bacteria Xenorhabdus nematophila can cause general immunodeficiency using toxins that jointly with nematode defenses overcome the insect's immune response [21]. Besides, Park and Kim [28] reported the ability of X. nematophila to avoid the activation of proPO cascade.

Our work is focused on Drosophila suzukii (Matsumura) (Diptera: Drosophilae) or spotted wing drosophila, the most important pest that attacks soft-skinned and small stone fruits causing significant losses to crops $[29,30]$. Despite chemical and culture methods are widely used, biological control of this fly has been attempted using natural enemies and entomopathogenic agents [31]. Studies with larvae of D. suzukii showed a strong immune response of encapsulation to parasitoid eggs of Leptopilina heterotoma Thompson (Hymenoptera: Figitidae) that discourages their use for controlling the pest [32,33]. Instead, pupal parasitoids, entomopathogenic fungi, and EPNs achieved better results controlling the fly under laboratory conditions [34-37]. Susceptibility of D. suzukii larvae was evaluated against different EPN species, as S. carpocapsae, Steinernema feltiae (Filipjev) (Rhabditida: Steinernematidae), and Heterorhabditis bacteriophora (Poinar) (Rhabditida: Heterorhabditidae) [36]. This study reported a high susceptibility of the fly after nematodes killed the larvae and reproduced inside them. Nevertheless, the immune response of D. suzukii to EPNs infection has not yet been studied.

Therefore, this work aimed to study the relationships between D. suzukii larvae and the nematobacterial complex S. carpocapsae/X. nematophila, from an immunological point of view. We evaluated humoral defenses, as the proPO system and lysozyme activity, the presence of antimicrobial peptides (AMPs) pool and its activity against bacteria. We analyzed the cellular response of $D$. 
suzukii larvae determining the phagocytosis and encapsulation ability of hemocytes and describing the immunoevasion strategies of S. carpocapsae.

\section{Materials and Methods}

\subsection{Chemicals and Instruments}

All reagents used in the assays were supplied by Sigma Chemicals (St. Louis, MO, USA), ICN (ICN Biomedicals, GmbH), Merck Millipore Ltd. (Tullagreen, Cork, Ireland), Bio-Rad Laboratories (Detroit, MI, USA). The equipment was supplied by Bio-Rad Laboratories (Detroit, MI, USA) and Celbio Spa (Milan, Italy, EU). Centrifugations were carried out with a SIGMA 1-14 (SciQuip Ltd., Newtown, Wem, Shropshire, UK) and an Eppendorf 5804R (Eppendorf, AG, Hamburg, Germany). Spectrophotometric assays were performed with a Jasco V-560 spectrophotometer (Easton, MD, USA). All materials, buffers, and solutions were autoclaved or filtered with $0.22 \mu \mathrm{m}$ Minisart filters (Sartorius, Goettingen, Germany). For microscopy observations, a microscope Olympus IX-51 epifluorescence connected to a Nikon digital camera was used.

\subsection{Insects and Nematodes}

The third stage of $D$. suzukii larvae used for all assays was obtained from a laboratory culture of specimens collected in Catalonia (NE Spain) in 2012. These insects were reared on a Drosophila diet [37] and maintained in a climate chamber at $25^{\circ} \mathrm{C}, 45 \% \mathrm{RH}$, and a $12: 12 \mathrm{~h}$ photoperiod.

The EPN species used in this study was S. carpocapsae (B14) isolated from urban garden soil in Barcelona (Catalonia, NE Spain). Nematodes were reared at $25^{\circ} \mathrm{C}$ in the last instar larvae of Galleria mellonella (Lepidoptera: Pyralidae) according to the method described by Woodring and Kaya [38]. The IJs emerging from insect cadavers were collected with modified White traps [39] and stored in sterile tap water in culture flasks at $9{ }^{\circ} \mathrm{C}$ for a maximum of two weeks. Before use, IJs were acclimatized at room temperature for $3 \mathrm{~h}$ and their viability was checked by observation of movement under a stereomicroscope. IJs were selected, washed several times with sterile phosphate buffer (PBS) $(8.0 \mathrm{~g}$ $\mathrm{NaCl}, 0.2 \mathrm{~g} \mathrm{KCl}, 1.44 \mathrm{~g} \mathrm{Na}_{2} \mathrm{HPO}_{4}, 0.24 \mathrm{~g} \mathrm{KH}_{2} \mathrm{PO}_{4}$ per liter, $\mathrm{pH} 7.4$ ), and centrifuged at $100 \times \mathrm{g}$ for $2 \mathrm{~min}$ at $20{ }^{\circ} \mathrm{C}$. Assays were performed using alive, dead and lipase-treated dead nematodes, to evaluate the role of the body surface of $S$. carpocapsae in the immune-evasive processes.

To kill the nematodes, they were frozen at $-20^{\circ} \mathrm{C}$ for at least $5-6 \mathrm{~h}$ in PBS plus $20 \%$ of glycerol. To modify the cuticular lipid layer, killed nematodes were treated with $50 \mu \mathrm{l}$ of lipase $(10 \mathrm{U} / \mu \mathrm{L}$ in $30 \mathrm{mM}$ of Tris- $\mathrm{HCl}, \mathrm{pH}$ 8), at $37^{\circ} \mathrm{C}$, for $90 \mathrm{~min}$; after the enzymatic digestion, nematodes were washed several times in sterile buffer.

\subsection{Bacteria Cultures and Infection Protocol}

To culture the symbiotic bacteria, X. nematophila were isolated from S. carpocapsae according to the method of Park and Kim [40]. X. nematophila Green Fluorescent Protein (GFP-labeled) was also kindly provided by the laboratory of Prof. Givaudan (University of Montpellier, France). Bacteria were inoculated into liquid broth $\left(30 \mathrm{~g} / \mathrm{L}\right.$ Tryptic Soy Broth) and incubated at $30{ }^{\circ} \mathrm{C}$ in agitation, overnight under dark conditions. The culture was grown to an optical density (OD) of 0.6 ; the growth curve was measured spectrophotometrically at $600 \mathrm{~nm}$. Bacteria were centrifuged at 1700 $\times \mathrm{g}$ for $20 \mathrm{~min}$ and bacterial pellets were washed several times with PBS. Aliquots at different concentrations were prepared for corresponding assays.

Cultures of Escherichia coli (C1a), Bacillus subtilis (ATCC $\mathrm{N}^{\circ}$ 6633), and Micrococcus luteus (ATCC $\mathrm{N}^{\circ} 4698$ ) were prepared for positive stimulation of D. suzukii larvae. Bacteria were inoculated and grown in Luria broth $(20 \mathrm{gr} / \mathrm{L})$ at $37^{\circ} \mathrm{C}$ and $30^{\circ} \mathrm{C}$ for M. luteus in agitation, overnight under dark conditions. Bacteria were grown up to $0.6 \mathrm{OD}\left(10^{9} \mathrm{CFU} / \mathrm{mL}\right)$ and were centrifuged at $1500 \times \mathrm{g}$ for $15 \mathrm{~min}$ at $20^{\circ} \mathrm{C}$. After centrifugation, the pellets were washed several times in PBS. Final bacterial concentrations and species mixtures were reported in each assay. 


\subsection{Hemolymph Collection}

To extract the hemolymph, third stage D. suzukii larvae were washed in PBS and 70\% ethanol solution and anesthetized at $4{ }^{\circ} \mathrm{C}$. Depending on the assay, 20 to 40 larvae were cut in the dorsal region with a microsurgical scissor and transferred in PCR tubes properly prepared for the procedure. The bottom of the tube was holed several times with a needle and inserted into a $0.5 \mathrm{~mL}$ Eppendorf so that during centrifugation, the hemolymph was collected in the large tube. Samples were centrifuged at $250 \times \mathrm{g}$ for $5 \mathrm{~min}$ at $4{ }^{\circ} \mathrm{C}$ to collect whole hemolymph containing hemocytes. For humoral assays (Section 2.6, Section 2.7), the supernatant, corresponding to a cell-free fraction (CFF), was recovered, centrifuged at $720 \times \mathrm{g}$ and a few phenylthiourea (PTU) crystals were added; all the humoral immunity assays were carried out according to the methods described in Mastore and Brivio [41]. For cellular assays (Section 2.8, Section 2.9), $10 \mu \mathrm{L}$ of PTU (from a saturated stock solution) were added to the whole hemolymph to prevent unwanted activation of phenoloxidase.

\section{5. proPO System Relative Activity in the Host Hemolymph}

To test the proPO activity of $D$. suzukii larvae against bacterial infection, phenoloxidase relative activity was analyzed in the hemolymph by spectrophotometric analysis with L-Dopa as a substrate.

Larvae of D. suzukii were washed with PBS and anesthetized by exposure to cold; then, they were infected with bacteria using a pricking method. Pricking consisted of a puncture with a wolfram needle soaked in bacteria pellet obtained from a suspension of $10^{9} \mathrm{CFU} / \mathrm{mL}$. Four different treatments were evaluated: naive larvae, control pricked larvae, X. nematophila infected larvae, and E. coli/B. subtilis infected larvae. A mixture of E. coli and B. subtilis 1:1 (v/v) was prepared. Larvae were kept at rearing conditions until hemolymph was collected 30 min after any treatment. After the extraction, the total protein content was determined and the reaction volumes were normalized according to concentration, $2.5 \mu \mathrm{L}$ of hemolymph was added in $1 \mathrm{~mL}$ of L-Dopa buffer (8 mM L-Dopa in $10 \mathrm{mM}$ Tris- $\mathrm{HCl}, \mathrm{pH}$ 7.2). The increase of absorbance was recorded at $490 \mathrm{~nm}\left(\Delta A_{490} 5 \mathrm{~min}^{-1}\right)$ at $25^{\circ} \mathrm{C}$, by a double-beam Jasco V-560 spectrophotometer (Easton, MD, USA) using L-Dopa buffer as blank. For each treatment, 20 larvae were used, and the experiment was repeated 5 times.

\subsection{Lysozyme Activity after Bacterial Infection}

To evaluate the activity of lysozyme in naïve and infected larvae of $D$. suzukii, the turbidimetric method was used with Micrococcus lysodeikticus as a substrate. This method is based on the decrease of absorbance due to the lysozyme-induced cell lysis determined as a unit of lysozyme produced in one minute a variation of OD $450 \mathrm{~nm}$ of 0.001 . Larvae of D. suzukii were infected with X. nematophila and E. coli/M. luteus mixture $1: 1(\mathrm{v} / \mathrm{v})$ at a concentration of $10^{9} \mathrm{CFU} / \mathrm{mL}$, using the pricking method. After infection, larvae were kept with diet at $25^{\circ} \mathrm{C}$ for $24 \mathrm{~h}$. Then, hemolymph samples were extracted from larvae, cells were removed and CFF samples, added with PTU crystals, were diluted with PBS (1:10). For the analysis, $0.45 \mathrm{mg} / \mathrm{mL}$ of $M$. lysodeikticus lyophilizate were resuspended in $0.3 \mathrm{M}$ PBS, pH 6.8 and mixed for $1 \mathrm{~min}$ at room temperature. For each treatment, $60 \mu \mathrm{L}$ of diluted CFF were added to $90 \mu \mathrm{L}$ of $M$. Iysodeikticus suspension into a well of 96-MicroWell ${ }^{\mathrm{TM}}$ plate. As a control, a suspension of $M$. lysodeikticus $(90 \mu \mathrm{L})$ plus PBS $(60 \mu \mathrm{L})$ was used, and a PBS $(90 \mu \mathrm{L})$ plus hemolymph sample $(60 \mu \mathrm{L})$ was used as a blank for each treatment. The activity of lysozyme was assessed immediately using a microplate-Reader (Bio-Rad, Hercules, CA, USA) and absorbance variations were recorded every $\mathrm{min}$ for $10 \mathrm{~min}$ at $450 \mathrm{~nm}$. For each treatment, 40 larvae were used, and the experiment was repeated three times.

\subsection{Analysis by Tricine-PAGE and Activity of AMPs}

We analyzed changes in proteins and peptides patterns in hemolymph samples (especially in CFF) of D. suzukii larvae using the electrophoretic separation by Tricine-SDS-PAGE methodology [42]. Moreover, the antimicrobial activity of these CFF samples was evaluated with bacteria growth tests. 
Larvae of D. suzukii were infected using the pricking method with a bacterial suspension of $X$. nematophila and E. coli/M. luteus mixture $1: 1(\mathrm{v} / \mathrm{v})$ at a concentration of $10^{9} \mathrm{CFU} / \mathrm{mL}$. Larvae were kept in rearing conditions for $24 \mathrm{~h}$. Then, the hemolymph from naïve infected X. nematophila and E. coli/M. luteus infected larvae was extracted. From these CFF samples, we carried out the analysis for the presence of putative AMPs molecules and the evaluation of the antimicrobial activity.

For the electrophoretic separations, hemolymph was fractioned by Amicon ${ }^{\circledR}$ Ultrafilters (Millipore, Burlington, MA, USA) cut-off $30 \mathrm{KDa}$ and precipitated with trichloroacetic acid $(20 \% \mathrm{~V} / \mathrm{V})$. Then, samples were resuspended in $1 \times$ Tricine-PAGE sample buffer [42] and denatured for $5 \mathrm{~min}$ at $100{ }^{\circ} \mathrm{C}$. Electrophoresis was carried by a vertical PROTEAN ${ }^{\circledR}$ II xi Cell (Bio-Rad) at $50 \mathrm{~V}$ (constant voltage) overnight. Protein patterns were detected by Silver Staining.

For the antimicrobial activity, CFF samples were centrifuged at $1700 \times \mathrm{g}$ for $15 \mathrm{~min}$ and fractioned $<30 \mathrm{kDa}$; E. coli, M. luteus, and X. nematophila cultures were diluted to a final concentration of $10^{6}$ $\mathrm{CFU} / \mathrm{mL}$ with culture broth. For each treatment, $20 \mu \mathrm{L}$ of CFF sample were added to $180 \mu \mathrm{L}$ of bacteria culture. To evaluate the expected bacterial growth, $20 \mu \mathrm{L}$ of PBS were added to the bacteria culture $(180 \mu \mathrm{L})$. All samples were incubated for $3 \mathrm{~h}$ under shaking at the optimal growth temperature of the tested bacterium. After incubation, $100 \mu \mathrm{L}$ of each sample was placed in a well of a 96-MicroWellim plate and samples were serially diluted with phosphate buffer $\left(61.4 \mathrm{mM} \mathrm{K}_{2} \mathrm{HPO}_{4}, 38.4 \mathrm{mM} \mathrm{H}_{2} \mathrm{PO}_{4}\right)$. Each dilution was plated on solid agar and incubated for $24 \mathrm{~h}$ more. Finally, bacteria colonies were counted. The antibacterial activity in hemolymph samples was intended as a percentage of bacterial survival compared with the control (bacterial suspension incubated without D. suzukii hemolymph). The final concentration of hemolymph total proteins used in the antimicrobial activity tests was 3.3 $\mu \mathrm{g} / \mu \mathrm{L}$. For each analysis and treatment, hemolymph of 40 larvae was extracted and the experiment was done three times.

\subsection{Phagocytic Activity Assay}

Phagocytic activity of $D$. suzukii hemocytes was evaluated both in vivo and in vitro in the presence of X. nematophila. For the in vivo assay, 60 larvae of D. suzukii were infected with X. nematophila-GFP $\left(10^{4}\right.$ $\mathrm{CFU} / 50 \mathrm{~nL}$ ). Microinjections were performed by a Drummond Nanoject II nanoliter injector (Drummond Scientific Company, PA, USA). As a positive control, 60 larvae were injected with $50 \mathrm{nl}(1 \mathrm{mg} / \mathrm{mL})$ of a suspension of pHrodo ${ }^{\circledR}$ Red Staphylococcus aureus Bioparticles ${ }^{\circledR}$-Conjugate (Life Technologies, Carlsbad, CA, USA). Larvae were kept in rearing conditions and hemolymph was collected after $2 \mathrm{~h}$. Extracted hemolymph with hemocytes was added to Schnëider medium in 96-MicroWell ${ }^{\mathrm{TM}}$ (Thermofisher Scientific, Waltham, MA, USA) plates (final concentration $2 \times 10^{5}$ cells $/ \mathrm{mL}$ ) and incubated for $30 \mathrm{~min}$ at $25^{\circ} \mathrm{C}$ in the dark. To evaluate the phagocytic activity of hemocytes, after adhesion, cells were observed under a fluorescence microscope.

For in vitro assay, hemolymph of 40 naïve larvae was extracted and hemocytes were plated in 96-MicroWell ${ }^{\mathrm{TM}}$ plates at a concentration of $2 \times 10^{5}$ cells $/ \mathrm{mL}$ in Schnëider medium. To allow cells to adhere to the substrate, plates were incubated for $1 \mathrm{~h}$ at $25^{\circ} \mathrm{C}$ in the dark. Then, $5 \mu \mathrm{L}\left(10^{3} \mathrm{CFU}\right)$ of X. nematophila-GFP or S. aureus-pHrodo ${ }^{\circledR}$ were added to cells and incubated for $4 \mathrm{~h}$ at $25^{\circ} \mathrm{C}$. After incubation, cells were observed under a fluorescence microscope to assess the phagocytic activity of hemocytes. Both experiments were performed three times.

\subsection{In Vitro Encapsulation Assay}

We assessed the ability of the hemocytes of $D$. suzukii larvae to recognize and encapsulate S. carpocapsae with an in vitro assay performed with three treatments. Alive IJs were used to test the physiological response of the host immune cells to the presence of the nematode. To exclude that unrecognition could be caused by active secretions, cold-killed nematodes were incubated with hemocytes. Besides, to investigate a possible mimetic function of the body-surface of $S$. carpocapsae, we modified the nematode cuticle using lipase enzyme treatment. 
Hemocytes from naïve larvae were extracted and plated with Schnëider medium in a 96-MicroWell ${ }^{\mathrm{TM}}$ plate $\left(2 \times 10^{5}\right.$ cells $\left./ \mathrm{mL}\right)$. Then, 5-10 nematodes per treatment (alive, cold-killed, or lipase-treated dead) were added to the microwells and incubated in a climate chamber at $25^{\circ} \mathrm{C}$. As positive control to evaluate encapsulation capability, we added 10-15 agarose beads (DEAE Sepharose ${ }^{\circledR}$ ) into wells. Encapsulation processes were monitored at different times along $24 \mathrm{~h}$ with an inverted fluorescence microscope. Each treatment was performed three times.

\subsection{Hemocytes Populations Count after Natural Infection}

To evaluate the in vivo ability of $D$. suzukii hemocytes to recognize and isolate $S$. carpocapsae, we carried out encapsulation assays by a natural infection. Concurrently, total and differential cell counts (plasmatocytes, lamellocytes, and crystal cells) were performed to assess any possible variation of cell populations after nematode infection.

Ten larvae were placed in a Petri dish $(3 \mathrm{~cm}$ diameter) filled with filter paper and exposed to $S$. carpocapsae $\left(50 \mathrm{IJs} \mathrm{cm}^{-2}\right)$ for $20 \mathrm{~h}$. The control treatment was carried out with sterile tap water. To detach any adherent cells from the hemocoel cavity, larvae were gently brushed, and then washed with PBS [43]. An incision was done behind the mandibles and all hemolymph (approximately $2 \mu \mathrm{L}$ ) was bled in $48 \mu \mathrm{L}$ of buffered PTU (saturated PTU diluted 1:4 in PBS). After bleeding, hemolymph content of each separated larvae was observed under the microscope, to detect the presence and number of nematodes inside the larvae, cell encapsulation processes, and the possible presence of symbiotic bacteria released in the hemolymph. Depending on the phase of infection, larvae were divided into two groups: early infection (only nematodes were present) or midterm infection (bacteria were released). Total hemocyte count was made applying the diluted hemolymph into the hemocytometer (Neubauer chamber, Brand $\left.{ }^{\circledR}\right)$. The cell counts were performed immediately by determining the total number of cell populations and the number of different types of hemocytes identified. For each treatment, ten larvae were evaluated, and the experiment was done twice.

\subsection{Statistical Analysis}

To analyze the differences in enzymatic activity of proPO and lysozyme, a General Linear Model (GLM) analysis has been used to ascertain differences among the tested samples. GLM was also used to elucidate differences among CFF samples of their antimicrobial activity against different bacterial cultures. Hemocyte counts were measured as the number of cells $/ \mu \mathrm{L}$ of hemolymph and differences among treatments were analyzed with GLMs. For all experiments, when the GLM was significant, differences were evaluated by Tukey test and means without transformation $( \pm S D)$ are presented. All statistical analyses were performed with the R studio software (version 1.0.153) [44], and any comparison was considered significant if the $p$-value was $<0.05$.

\section{Results}

\section{1. proPO System Relative Activity in the Host Hemolymph}

The relative activity of phenoloxidase enzyme in D. suzukii samples was evaluated by recording spectrophotometrically the formation of dopachrome (Figure 1, Figure S1, and Table S1). 


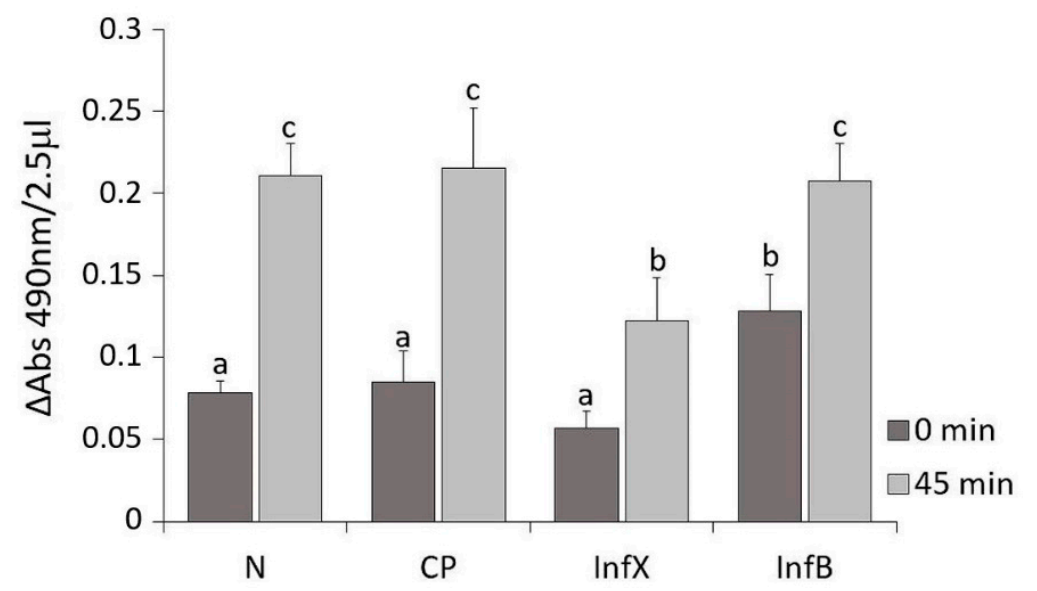

Figure 1. Phenoloxidase relative activity in the hemolymph of D. suzukii shown as the mean $\pm \mathrm{SD}$ increase of absorbance, recorded at 0 and $45 \mathrm{~min}(=490 \mathrm{~nm})$, in hemolymph samples from naïve (N), control pricked (CP), X. nematophila-infected (InfX) and E. coli/B. subtilis-infected (InfB) larvae. Different letters indicate statistical significance differences between hemolymph samples $(p<0.05)$.

Samples from naïve larvae $(\mathrm{N})$, control pricked larvae $(\mathrm{CP})$, infected larvae with X. nematophila (InfX) and infected larvae with E. coli/B. subtilis (InfB) were analyzed. The absorbance values recorded showed no significant difference between naïve and control pricked larvae. These values represent the physiological activity of the enzyme until the formation of all dopachrome (time $45 \mathrm{~min}$ ). Larvae infected with $X$. nematophila presented similar values to both naïve and control larvae at $0 \mathrm{~min}$, but the presence of symbiotic bacteria produced an inhibition of phenoloxidase activity $45 \mathrm{~min}$ after the start of reaction. The enzyme showed a significantly minor activity compared to the other hemolymph samples (GLM: $F=42, d f=7, p<0.001$ ). In contrast, the proPO system of $D$. suzukii larvae resulted in E. coli and B. subtilis infection showing a significantly high increase of absorbance at $0 \mathrm{~min}$ after hemolymph extraction.

\subsection{Lysozyme Activity after Bacterial Infection}

The assays of lysozyme activity in the hemolymph of naïve $D$. suzukii larvae showed extremely low activity $\left(1 \times 10^{-1}\right.$ Units $\left.\mathrm{mL}^{-1}\right)$. Moreover, those infected with $X$. nematophila also presented a low level of activity $\left(1.1 \times 10^{-1}\right.$ Units $\left.\mathrm{mL}^{-1}\right)$. Only after infection with $E$. coli and $M$. luteus, a slight increase in the enzyme activity was recorded $\left(1.3 \times 10^{-2}\right.$ Units $\left.\mathrm{mL}^{-1}\right)$. Nevertheless, lysozyme activity in the hemolymph of $D$. suzukii larvae was not significantly stimulated by the infection of $X$. nematophila or the bacterial mixture of E. coli and M. luteus (GLM: $F=0.12, d f=2, p=0.81$ ).

\subsection{Analysis by Tricine-PAGE and Activity of AMPs}

Electrophoretic separation of fractioned CFF ( $<30 \mathrm{kDa})$ showed proteins and peptide patterns of hemolymph samples from naïve and infected larvae (Figure 2). 


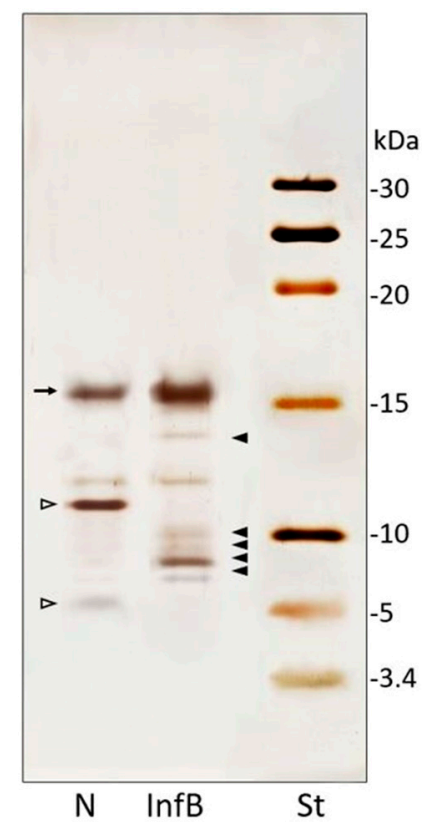

Figure 2. Tricine-SDS-PAGE (16\%) of hemolymph samples. Patterns of low molecular weight proteins $(<30 \mathrm{kDa})$ of hemolymph from naïve $(\mathrm{N})$ and E. coli/M. luteus-infected (InfB) larvae; standard molecular weights marker (St). Full arrowheads indicate newly synthesized bands and the arrow an increased band, observed after bacterial infection. Empty arrowheads indicated disappeared peptides after bacterial infection.

In naïve larvae $C F F$, four main bands were present and two of them disappear in the infected larvae sample (Figure 2, empty arrowhead). Moreover, peptides pattern from D. suzukii larvae infected with $X$. nematophila (Figure S2) and infected with the mixture of E. coli/M. luteus showed newly synthesized or quantitatively increased peptides of low molecular weight (Figure 2, full arrowheads). Five main bands, ranging from 5 to $16 \mathrm{kDa}$, absent in CFF from naïve larvae (Figure 2, N), were observable in samples from treated larvae (Figure 2, InfB). Moreover, a band of about $16 \mathrm{kDa}$, increased in samples from infected larvae (Figure 2, InfB, arrow). The infection with X. nematophila (Figure S2) and E. coli/M. luteus resulted in the disappearance of two peptides (Figure 2, N, empty arrowheads).

After identification of the peptides pattern, the antimicrobial activity in the hemolymph was analyzed by co-incubation of CFF samples with bacterial cultures of E. coli, M. luteus, and X. nematophila. Bacterial growth $(\mathrm{CFU} / \mathrm{mL})$ represented a negative correlation of AMPs activity present in larvae hemolymph of naïve, infected with X. nematophila and infected with E. coli/M. luteus (Figure 3, Table S2).

As there was significant higher proliferation of all bacteria incubated with naive hemolymph compared to buffer incubation (PBS), we evaluated the bacterial mortality percentage assuming as $100 \%$ the data obtained with naive hemolymph samples (Table S3). CFF samples from larvae infected with X. nematophila reduced significantly the bacterial growth of E. coli to $6.11 \times 10^{7} \mathrm{CFU} / \mathrm{mL}$ and $M$. luteus to $3.86 \times 10^{7} \mathrm{CFU} / \mathrm{mL}$. These results showed a degree of antimicrobial activity in hemolymph against both bacteria strains with $55.0 \%$ and $41.5 \%$ of mortality respectively (Table S3). However, CFF samples of E. coli/M. luteus-infected larvae presented a drastic antimicrobial effect against E. coli $(1.06 \times$ $\left.10^{7} \mathrm{CFU} / \mathrm{mL}\right)$ causing mortality of $92.2 \%$ and $76.1 \%$ against $M$. luteus $\left(1.58 \times 10^{7} \mathrm{CFU} / \mathrm{mL}\right)$. In contrast, when tested on X. nematophila the recorded mortality was markedly lower (17.2\%) (Table S3). Thus, CFF from larvae infected with $X$. nematophila showed antimicrobial activity against the three bacterial cultures tested, although lower than the obtained after E. coli/M. luteus infection. 


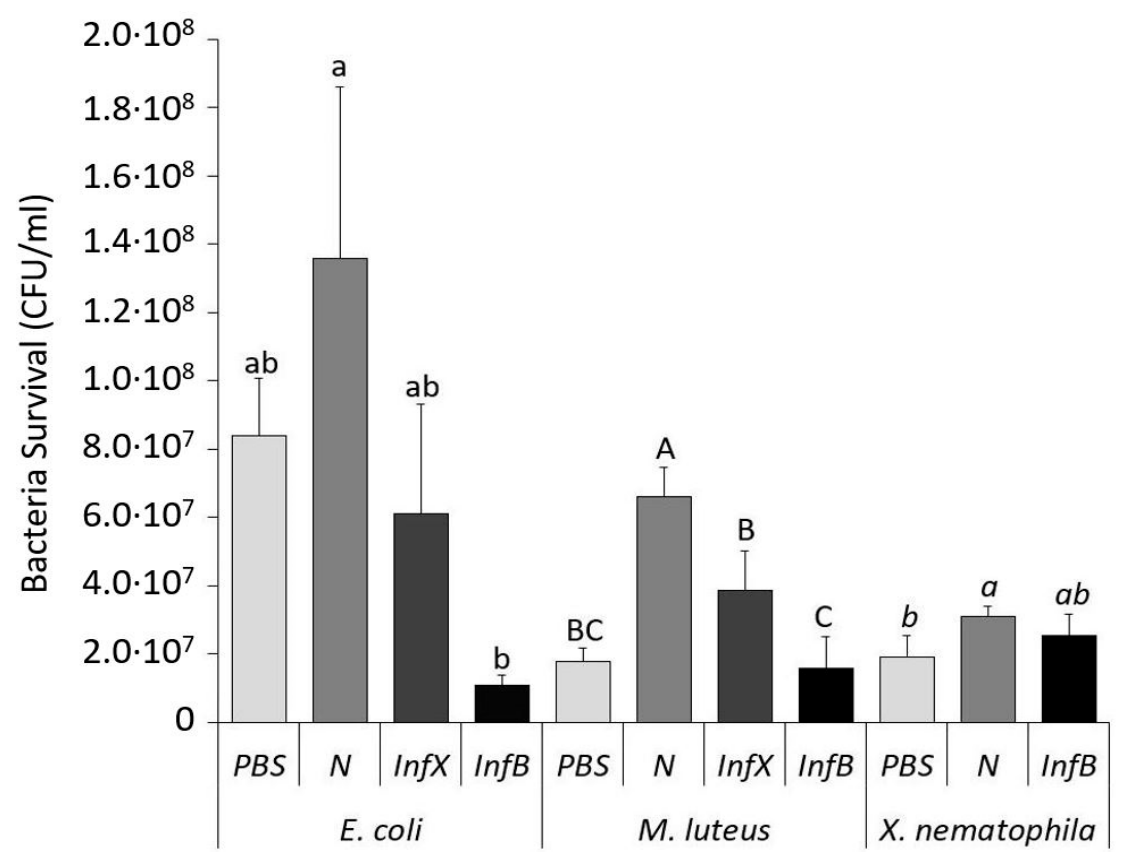

Figure 3. Antimicrobial activity of D. suzukii hemolymph after bacterial infection evaluated through co-incubation with E. coli, M. luteus, and X. nematophila. Host hemolymph samples were from PBS-control (PBS), naïve larvae (N), infected with X. nematophila (InfX), and with E. coli/M. luteus (InfB). Survival of E. coli, M. luteus, and X. nematophila are shown as the mean $\pm \mathrm{SD}$ of CFU/ml. Different letters on the bars represent statistically significant differences among each antimicrobial sample. GLM of E. coli: $F=8.39, d f=3, p=0.007$; GLM of M. luteus: $F=21.73, d f=3, p<0.001$; GLM of X. nematophila: $F=3.66, d f=2, p=0.091$.

\subsection{Phagocytic Activity Assay}

During in vivo phagocytosis assay, hemolymph of $D$. suzukii larvae injected with $X$. nematophila-GFP was extracted and monitored by fluorescence microscopy.

To evaluate the phagocytosis capability of hemocytes, we carried out in vivo assays using S. aureus pHrodo ${ }^{\circledR}$-conjugated which fluorescence was activated only at acidic $\mathrm{pH}$ (inside phagolysosomes). Staphylococcus aureus-pHrodo was effectively engulfed by host cells as confirmed by the intense fluorescence of the probe (pHrodo) (Figure 4, A1, left). Besides, in the bright field, hemocytes of $D$. suzukii were properly adhered to the substrate and are viable and showing a morphology typical of cells that have engulfed (Figure 4, A1, right). Otherwise, hemocytes seem to be unable to phagocytize X. nematophila-GFP (Figure 4, A2, left); both the elongated rod shape and swipes of the symbiont bacteria, indicate their extracellular localization. The entomopathogenic bacteria, in addition to not being phagocytized, seem to have cytotoxic effects on the host hemocytes, affecting the morphology of the cells (Figure S3). Besides, Figure 4 (A2, right) shows the micrograph obtained by combining fluorescence and phase contrast, in which the extracellular location of the symbiont bacteria can be detected. 

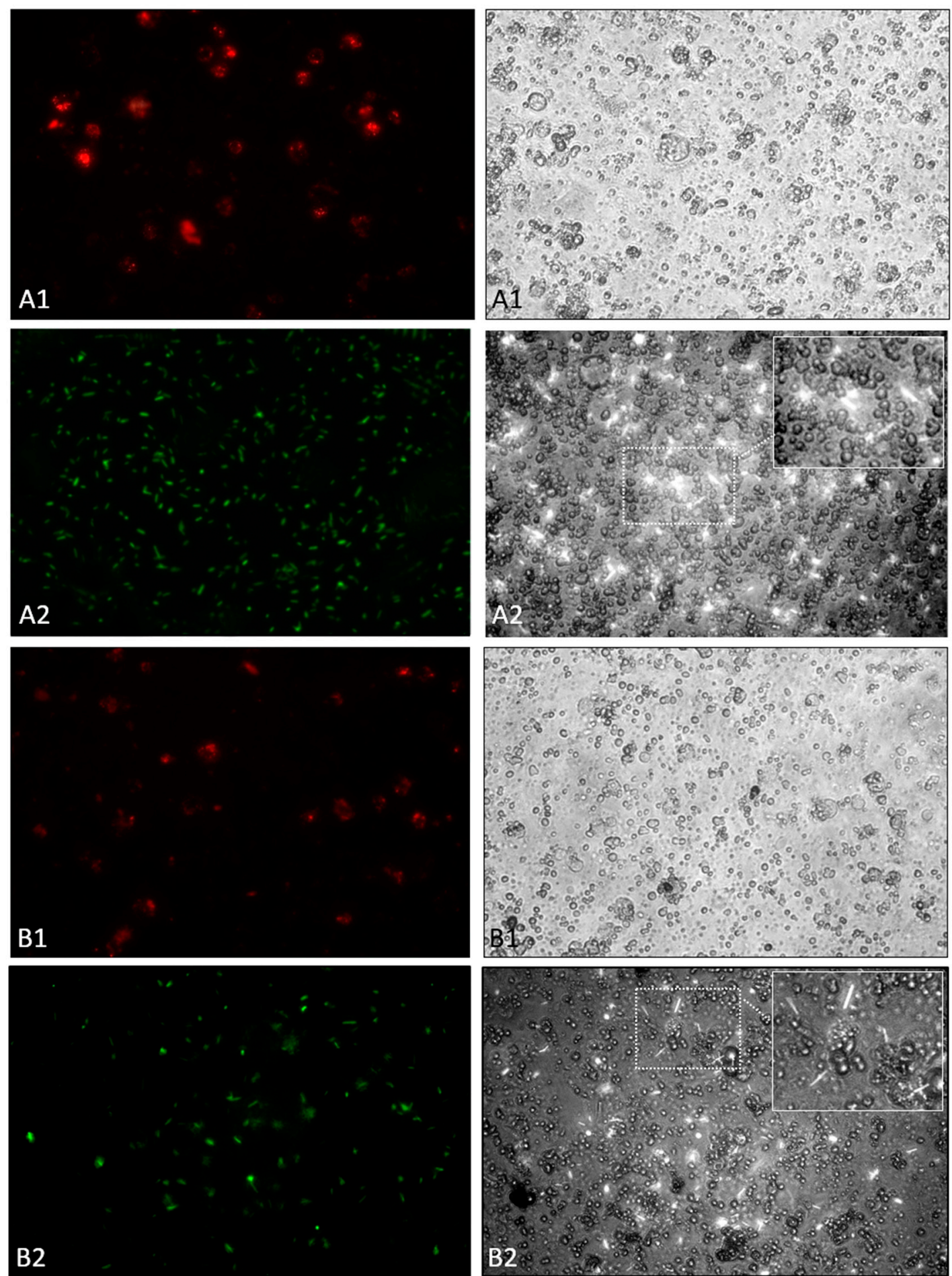

Figure 4. In vivo (A) and in vitro (B) phagocytic activity of D. suzukii larvae hemocytes against bacteria. (A1) in vivo assay at $2 \mathrm{~h}$ with $S$. aureus-pHrodo ${ }^{\text {TM }}$ BioParticles ${ }^{\circledR} ;($ A2) in vivo assay at $2 \mathrm{~h}$ with $X$. nematophila-GFP, inside A2 right an enlargement of the central area of the image. (B1) in vitro assay at 4 $\mathrm{h}$ with S. aureus-pHrodo ${ }^{\mathrm{TM}}$ BioParticles ${ }^{\circledR} ;$ (B2) in vitro assay at $4 \mathrm{~h}$ with X. nematophila-GFP, inside B2 right an enlargement of the central area of the image. All images on the right are bright field of the respective fluorescence micrographs on the left. Images magnification is $400 \times$.

Hemocytes of $D$. suzukii larvae established in the in vitro cultures showed comparable results to those obtained in vivo; S. aureus-pHrodo was efficiently phagocytized (Figure 4, B1, left) and hemocytes 
show the morphology of cells that are engulfing (Figure 4, B1, right). When X. nematophila-GFP was added to the culture, hemocytes were not able to phagocyte the symbiont bacteria as confirmed by the observation of Figure 4, B2, left and right.

\subsection{In Vitro Encapsulation of S. carpocapsae}

Cellular encapsulation of nematocomplexes was assessed using in vitro long-term co-incubation. Hemocyte response against $S$. carpocapsae alive, dead (cold-killed), or surface lipase-treated was monitored under an inverted microscope for $24 \mathrm{~h}$. We observed that alive nematodes were not recognized nor encapsulated by hemocytes even after $24 \mathrm{~h}$ (Figure 5A,B: A1,A2,A3,A3i).

Moreover, no cellular processes directed against $S$. carpocapsae were evident. We performed the same experiment with cold-killed nematodes to exclude the influence of active secretions. As seen before, hemocytes were unable to recognize dead IJs of $S$. carpocapsae and no encapsulation processes were observed also at long times (Figure 5A,B: B1,B2,B3,B3i). When lipase-treated nematodes were used, it was possible to observe a reactivity of hemocytes adhering to the body surface of the treated nematodes (Figure 5C,D: C1 and C1i, C2 and C2i). After $2 \mathrm{~h}$ (Figure 5, C1), numerous layers of cells were attached to the cuticle and would contribute to the building of the cellular capsule. The abiotic targets (Sepharose DEAE microbeads) used as a control presented cellular reactivity with hemocytes adhered to beads and the presence of melanin clots at 12 and $24 \mathrm{~h}$ after incubation (Figure 5C,D: D1 and D2, respectively).
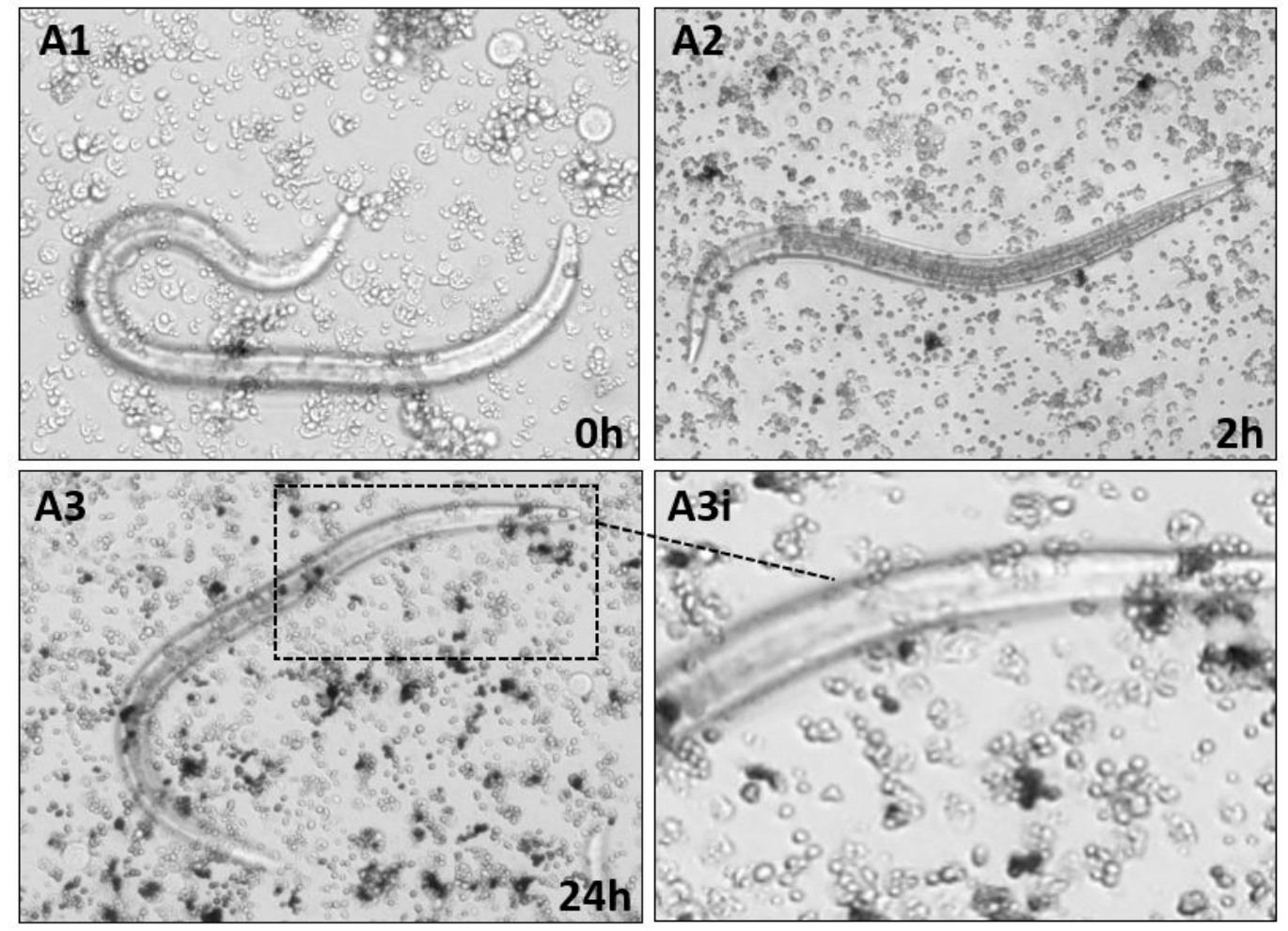

Figure 5. Cont. 

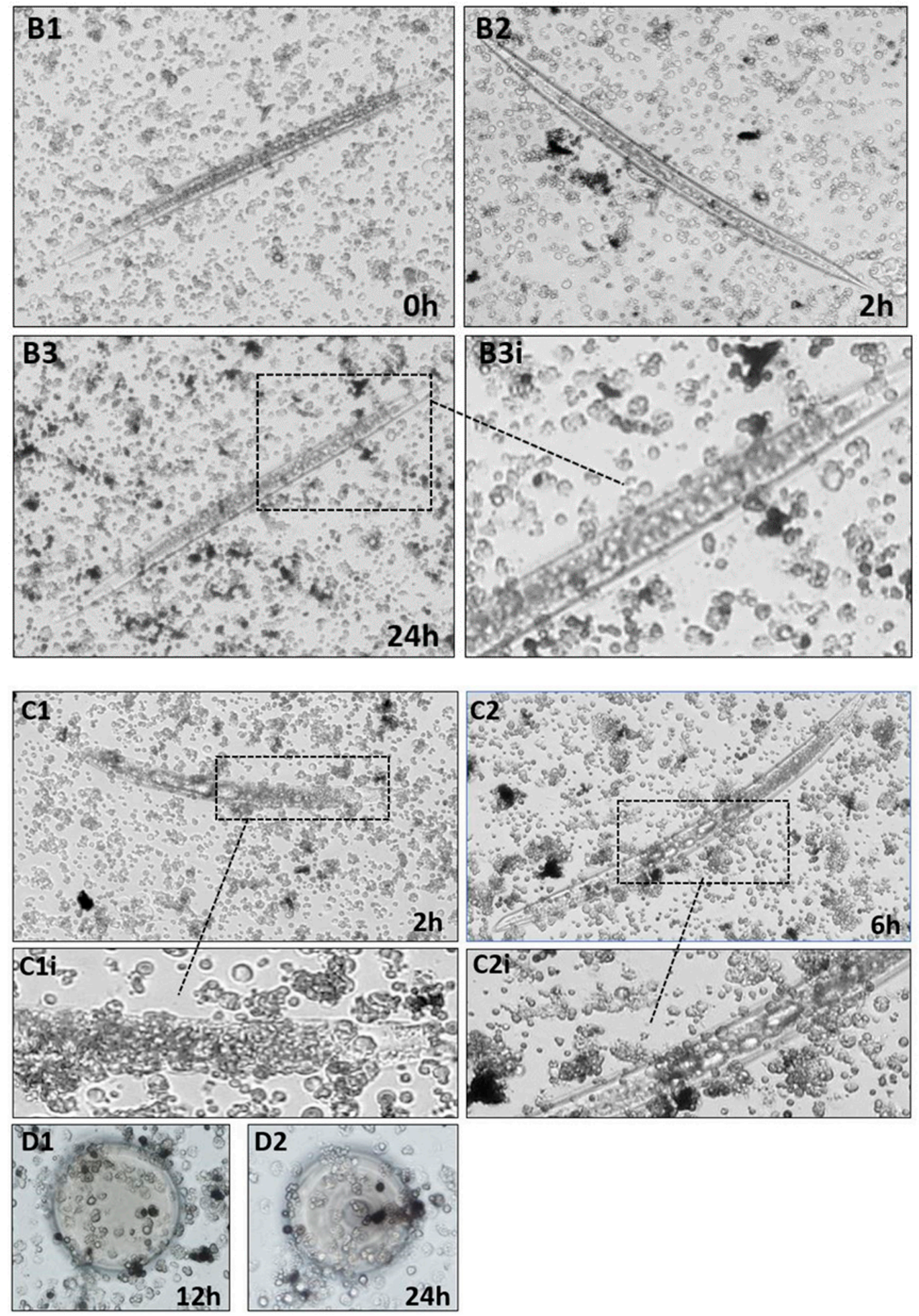

Figure 5. (A,B) In vitro encapsulation assays of S. carpocapsae by hemocytes of D. suzukii larvae. Nematodes were co-incubated with hemocytes. From top to bottom: alive nematodes at $0 \mathrm{~h}$ (A1), $2 \mathrm{~h}$ (A2) and $24 \mathrm{~h} \mathrm{(A3),} \mathrm{A3i} \mathrm{inset} \mathrm{is} \mathrm{an} \mathrm{enlargement} \mathrm{of} \mathrm{A3.} \mathrm{Cold-killed} \mathrm{nematodes} \mathrm{at} 0 \mathrm{~h}$ (B1), $2 \mathrm{~h}$ (B2), and $24 \mathrm{~h}$ (B3), B3i inset is an enlargement of B3. A1 (200x); A2, A3, B1, B2, B3 (100×). (C,D). In vitro encapsulation assay of lipase treated dead nematodes at $2 \mathrm{~h}(\mathrm{C} 1)$ and $6 \mathrm{~h}(\mathrm{C} 2), \mathrm{C} 1 \mathrm{i}$ and $\mathrm{C} 2 \mathrm{i}$ are enlargements of the respective images. In vitro encapsulation of agarose beads, at $12 \mathrm{~h}$ (D1) and $24 \mathrm{~h}$ (D2). C1 and C2 (100x); D1 and D2 (200×). 


\subsection{Hemocytes Populations Count after Natural Infection}

Natural infection of S. carpocapsae in D. suzukii larvae showed no cellular encapsulation processes of nematodes, as we observed in the previous in vitro assay. IJs were found free without attached cells on the cuticle, even if X. nematophila was released in the hemolymph. Hemocyte counts were performed when the mean number of nematodes inside larvae was $5.9 \pm 4.3$ IJs. Counts were avoided when the nematode number was over 15 IJs because the massive entry of nematodes into small larvae like D. suzukii generate tissue damage quickly. Infected larvae were separated in the early phase or midterm phase of infection if bacteria were released. Larvae in the early phase were mostly still alive $(95 \%)$, while $30 \%$ of larvae were alive in the midterm phase.

Total hemocytes count showed a high number of immunocompetent cells $\left(2.63 \times 10^{4} \mathrm{cells} / \mu \mathrm{l}\right)$ in naive $D$. suzukii larvae hemolymph (Table 1 ).

Table 1. * Evaluation of hemocytes population (mean $\pm \mathrm{SD}$ ) of total and differential count of three D. suzukii larvae treatments: naïve larvae (no infected), early phase of infection (with only nematode presence) and midterm phase of infection (nematode and bacterial presence). Different letters indicate statistically significant differences among treatments for each cell type $(p<0.05)$.

\begin{tabular}{ccccc}
\hline \multicolumn{5}{c}{ Hemocyte Number/ $\mu$ L of Hemolymph * } \\
\hline Treatment & Plasmatocytes & Lamellocytes & Crystal Cells & Total Hemocytes \\
\hline Naïve & $25446.88 \pm 4358.13 \mathrm{a}$ & $195.63 \pm 49.88 \mathrm{a}$ & $677.50 \pm 296.88 \mathrm{a}$ & $26320.00 \pm 4311.47 \mathrm{a}$ \\
Early phase & $18676.88 \pm 3676.56 \mathrm{~b}$ & $564.38 \pm 156.24 \mathrm{~b}$ & $745.00 \pm 184.04 \mathrm{a}$ & $19986.25 \pm 3733.23 \mathrm{~b}$ \\
Midterm phase & $20293.75 \pm 3790.60 \mathrm{~b}$ & $183.75 \pm 54.73 \mathrm{a}$ & $841.88 \pm 341.27 \mathrm{a}$ & $21319.38 \pm 3791.21 \mathrm{~b}$ \\
\hline
\end{tabular}

Nevertheless, infected larvae showed a significant decrease in total hemocytes in the early and midterm phase of infection (GLM: $F=14.26, d f=2, p=0.000$ ). Plasmatocytes constituted the major fraction of hemocytes and presented a decrease in both phases of infection, as total hemocytes (GLM: $F$ $=16, d f=2, p=0.000$ ). In naïve larvae, lamellocytes represent a very small fraction of immune cells but during the early phase of infection, the amount of lamellocytes increased significantly (GLM: $F=93.99$, $d f=2, p=0.000$ ). During the midterm phase, the bacteria were released, and we observed the attachment of lamellocytes and plasmatocytes with themselves, becoming big aggregations (Figure 6A,B). Due to the difficulty of counting only free cells were considered. In consequence, lamellocytes level decreased showing no significant difference with naïve value.

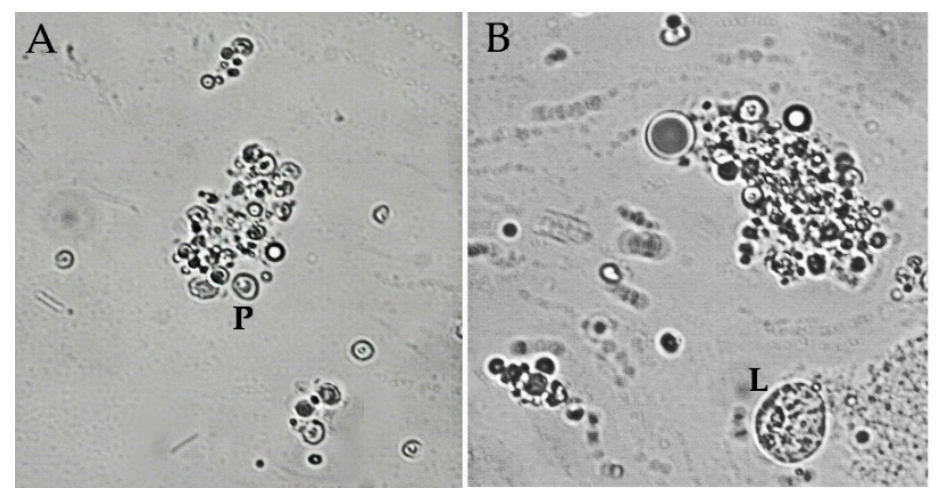

Figure 6. (A) Plasmatocytes (P) aggregation in in vivo encapsulation assay during the midterm phase of infection. (B) Aggregation of hemocytes next to a circulant lamellocyte (L). Image magnification is $400 \times$. 
Nevertheless, IJs were not found close to these cell aggregations. The only hemocytes population that seemed unaffected by nematode infection were the crystal cells. Neither nematode nor bacterial infection altered the number of crystal cells that remained constant in all assays (GLM: $F=1.71, d f=2$, $p=0.188)$.

\section{Discussion}

D. suzukii represents a major threat to berry, cherry, and strawberry production as a globally invasive pest. This fly belongs to the melanogaster subgroup, as well as Drosophila melanogaster (Meigen) (Diptera: Drosophilidae), which immune response to EPNs is widely studied as an insect model $[18,43]$. In contrast, few immunological studies have been conducted with $D$. suzukii and only focused on the parasitoid response. Poyet et al. [33] described a strong immune reaction against the parasitoid $L$. heterotoma, which leads to the encapsulation of wasp eggs. Even if D. suzukii larvae and adults are susceptible to nematodes [36], no immunological studies on the relationships between these pests and EPNs have been made before; consequently, we evaluated humoral and cellular responses upon infection of $S$. carpocapsae and X. nematophila.

The fastest defense of insect larvae is the activation of the phenoloxidase cascade. The symbiont bacteria $X$. nematophila showed an inhibitory effect on the host proPO system, with levels of phenoloxidase activity lower than naïve larvae. In contrast, E. coli and B. subtilis infection registered higher activity. These results agree with those obtained comparing the melanization rate of $D$. melanogaster infected with symbiont and axenic S. carpocapsae [45]. These authors reported that in the presence of $X$. nematophila, levels of melanization were significantly lower than using the axenic nematode. The inhibitory role of this symbiont bacteria and involvement of the eicosanoid pathway has been also reported in some lepidopteran species such as Spodoptera exigua (Hübner) (Lepidoptera: Noctuidae) and Plutella xylostella L. (Lepidoptera: Plutellidae) [28,46]. These authors related the secretion of a phospholipase $\mathrm{A}_{2}\left(\mathrm{PLA}_{2}\right)$ inhibitor with the suppression of the proPO activation in hemolymph and the alteration of cellular response. Despite no homologous genes were identified in D. melanogaster, Scarpati et al. [47] found other genes involved in eicosanoid pathway that could be functional equivalents.

The assay of lysozyme activity in naïve larvae of $D$. suzukii showed an extremely low activity compared to other insect species such as Galleria mellonella (Lepidoptera) $2.28 \times 10^{3}$ Units $\mathrm{mL}^{-1}$ or Sarcophaga africa (Diptera) $1.04 \times 10^{2}$ Units $\mathrm{mL}^{-1}$ [48]. There was no significant difference when larvae were stimulated by bacteria. Thus, lysozyme activity was not triggered by the infection X. nematophila nor E. coli/M. luteus. In agreement with our results, the Drosophila genus showed to have mainly digestive lysozyme and an insignificant amount of enzyme in the hemolymph for immune defense [49].

Along with phenoloxidase and lysozyme enzymes, AMPs perform a key role in humoral defense against bacterial infection. When AMPs presence was assessed by electrophoretic separations, both bacterial infections showed comparable band patterns with newly synthesized bands compared to naive larvae. However, the antimicrobial activity test revealed a higher activity of the bacterial mixture infected larvae as opposed to larvae infected with X. nematophila. These results suggested that there was a synthesis of putative AMPs after symbiont infection. Nevertheless, larvae infected with X. nematophila showed lower activity with respect to that from larvae infected with non-entomopathogenic bacteria. With the conducted assay, we are unable to determine the causes, although these results could suggest an active mechanism of X. nematophila to disable the activity of those peptides. Some authors attributed to symbionts bacteria the ability to down-regulate AMPs genes in S. exigua or Rynchophorus ferrugineus Olivier (Coleoptera: Curculionidae) [50-52]. However, Peña et al. [45] reported in D. melanogaster an increased gene expression of AMPs in response to X. nematophila infection, over an infection of S. carpocapsae. Indeed, genes could be up-regulated in D. suzukii, as we detected the presence in the hemolymph of some peptides in the molecular mass range of AMPs. Although, the symbiont bacteria are known to release cytotoxic proteins and antimicrobial inhibitors to block the function of the peptides [53]. 
In addition to the analysis of humoral responses, we have also observed interference of the nematobacterial complex with the host cellular responses. As observed, either in in vivo or in vitro assays, X. nematophila was able to avoid phagocytosis response by the host immunocompetent cells; the phagocytic capability of the hemocytes was ascertained by the assays with $S$. aureus. Shrestha and Kim [54] reported in S. exigua larvae that the disruption of phagocytosis and avoidance of cell reaction to bacteria was caused by the synthesis of PLA 2 inhibitors by X. nematophila. Similar results were also obtained with Manduca sexta L. (Lepidoptera: Sphingidae) larvae, where E. coli was engulfed more than Photorhabdus luminescens (the symbiont bacteria of $H$. bacteriophora) [55]. Both symbionts bacteria use inhibitor of the $\mathrm{PLA}_{2}$; likewise, in D. suzukii larvae, X. nematophila could implement the same strategy to avoid the host phagocytosis. Our data showed the ability of $S$. carpocapsae to avoid encapsulation of D. suzukii hemocytes in both in vitro and in vivo assays. Besides, nematode secretions do not seem to play a central role in the lack of encapsulation as we confirmed using dead IJs with unaltered cuticle. Encapsulation was only observed when the cuticle of nematodes was damaged after lipase treatment, suggesting an involvement of the body surface to avoid cellular recognition. Mastore et al. [26] reported similar results demonstrating a lack of encapsulation of alive and dead S. carpocapsae IJs in R. ferrugineus, although damaged cuticles of nematodes were strongly encapsulated. Furthermore, S. carpocapsae avoided the recognition by G. mellonella hemocytes while H. bacteriophora was recognized [56]. It has been described that $S$. carpocapsae have specific proteins in the epicuticle of IJs that provide a mimetic function to the nematode [23]; besides, in S. feltiae, disguise properties could be ascribed to lipids of the epicuticular layer, as suggested by Dunphy and Webster [57]. According to Brivio et al. [22,58], differences observed between S. carpocapsae and S. feltiae in the immunological relationships with their hosts supported the assumption that EPNs have developed peculiar immunoevasive strategies among different species.

During the in vitro encapsulation assay, a lack of lamellocyte differentiation was observed and resulted in the achievement only of the first steps of an encapsulation process with the attachment of plasmatocytes to lipase-treated nematodes and agarose beads. In contrast, in vivo assays evidenced the lamellocytes differentiation process after nematode infection, causing a decrease of plasmatocytes and an increase of lamellocytes from the constitutive level. The divergence of the differentiation process between assays could be expected due to a lack of natural physiological factors during in vitro assays. Moreover, the cell counts obtained during the in vivo assay showed a high amount of hemocyte populations, in agreement with Kacsoh and Schlenke [59] who suggested that D. suzukii larvae had five times more immunocompetent cells than $D$. melanogaster. The results of this assay also confirmed the lack of encapsulation of $S$. carpocapsae despite the differentiation of lamellocytes in the early phase of infection. During the midterm phase of infection, lamellocytes-plasmatocytes aggregation prevented counting hemocytes due to large cellular aggregates whose composition was not identifiable. An important role in the strategy of S. carpocapsae is attributable to its secretions of proteases and cytotoxic compounds which induce immunosuppression to the host. Some of these secretions have been identified as serine, cysteine, metallo, and aspartic proteases involved in processes of cell aggregation, clotting response, and cellular apoptosis $[25,60]$. These authors reported that when S. carpocapsae infects D. melanogaster, avoids clot enlargement by means of its inhibitor sc-spn6. Unlike plasmatocytes and lamellocytes, our assay crystal cell population remained unaffected even after the nematode released the bacteria. The regular count corroborated the low levels of melanization response observed whereas those cells produced and stored the components of proPO cascade. These results confirmed the different responses of $D$. suzukii larvae to parasitoids as their eggs activate the proPO reaction and cause a strong loss of crystal cells [33]. Moreover, the cellular response of the fly larvae to $L$. heterotoma or L. boulardi eggs presented the same pattern with a significant increase of plasmatocytes and lamellocytes $[33,59]$. In contrast, D. suzukii larvae showed a cellular response to Asobara japonica Belokobylskij (Hymenoptera: Braconidae) eggs more similar to nematode's reaction observed in this work, with a slight decrease of plasmatocytes and similar constitutive levels of lamellocytes after long-term parasitization [33]. 
Our immunological approach aimed to investigate the relationship between an insect pest, such as D. suzukii and EPNs to provide an essential understanding of the strategies by which nematobacterial complexes overwhelm the host defenses. The results reported the inhibitory properties of both $S$. carpocapsae and X. nematophila to larvae's immune defenses. Symbiont bacteria affected the humoral response of proPO resulting in lower levels of phenoloxidase activity. In addition, X. nematophila infection activated the synthesis of putative AMPs molecules, although their antimicrobial activity was lower than peptides produced from infections with non-entomopathogenic bacteria. Besides, the cell populations of D. suzukii were unable to phagocyte the symbiont bacteria or encapsulate $S$. carpocapsae IJs. The data obtained from the encapsulation assays confirmed the elusive properties of the body surface of $S$. carpocapsae. These results attribute to the cuticle a synergistic role with its secretions to prepare an immunologically favorable environment before the release of the symbiont in the hemocoel cavity.

\section{Conclusions}

Along this work, S. carpocapsae and X. nematophila showed the ability to overtake the immune defenses of D. suzukii, therefore confirming the potentiality of this nematode as a biological control agent for this pest. This is the first report that addresses the physiological relationship between EPNs and D. suzukii from an immunological aspect; thus, providing a useful starting point to understand the parasite-host relationship between these organisms and help to improve the biological control of D. suzukii.

Supplementary Materials: The following are available online at http://www.mdpi.com/2075-4450/11/4/210/s1. Figure S1. Time course of phenoloxidase relative activity in the hemolymph of D. suzukii, shown as mean \pm SD increase of absorbance recorded every $5 \mathrm{~min}$ for $45 \mathrm{~min}$ total. Hemolymph samples were from naïve $(\mathrm{N})$, control pricked (CP), X. nematophila-infected (InfX), and E. coli/B. subtilis-infected (InfB) larvae. Figure S2. The tricine-PAGE pattern of fractioned hemolymph $(<30 \mathrm{KDa})$ extracted from larvae after X. nematophila infection. Even though the pattern showed some bands comparable to that observed in E. coli/M. luteus-infected larvae, this sample, tested for antimicrobial capability, revealed lower activity compared with that of larvae infected with non-entomopathogenic bacteria. Figure S3. Plated D. suzukii hemocytes from naive larvae (A) and X. nematophila infected-larvae (B). Micrographs below (B1, B2, and B3) show the altered morphology of the hemocytes with blebs (arrowheads) protruding from the cell surface. In the micrographs of healthy cells (A) lamellipodia (arrowheads) are visible. Table S1. Statistic comparison of phenoloxidase relative activity in the hemolymph of D. suzukii of Figure 1. $P$-value obtained in the Tukey comparison of the hemolymph samples from naïve (N), control pricked (CP), X. nematophila-infected (InfX) and E. coli/B. subtilis-infected (InfB) larvae, at 0 min and 45 min. Any comparison was considered significant if the $p$-value was $<0.05$. Table S2. Statistic comparison of antimicrobial activity in D. suzukii hemolymph of Figure 3. p-value obtained in the Tukey comparison of the hemolymph samples from naïve (N), control (PBS), X. nematophila-infected (InfX), and E. coli/B. subtilis-infected (InfB) larvae, in coincubation with E. coli, M. luteus, or X. nematophila. Any comparison was considered significant if the $p$-value was $<0.05$. Table S3. Mortality rate (\%) of E. coli, M. luteus, and X. nematophila, when treated with D. suzukii hemolymph from larvae infected with InfB or InfX.

Author Contributions: Conceived idea, A.M. and F.G.d.P.; conceptualization, M.F.B., M.M., and A.G.; methodology, M.M., A.G., and M.F.B.; investigation, A.G. and M.M.; data curation, A.G., M.M., and M.F.B.; writing-original draft preparation, A.G.; writing-review and editing, M.F.B., M.M., A.G., F.G.d.P., and A.M.; project supervision and administration, F.G.d.P. and M.F.B.; funding acquisition, F.G.d.P. and M.F.B. All authors have read and agreed to the published version of the manuscript.

Funding: This research was supported by FEDER/Ministerio de Ciencia, Innovación y Universidades-Agencia Estatal de Investigación/Project (AGL2017-86770-R) and University of Insubria, FAR grant/2018.

Acknowledgments: We are very grateful to Alain Givaudan for kindly providing us with the GFP-transformed Xenorhabdus strains.

Conflicts of Interest: The authors declare no conflict of interest.

\section{References}

1. Kaya, H.K.; Gaugler, R. Entomopathogenic nematodes. Annu. Rev. Entomol. 1993, 38, 181-206. [CrossRef]

2. Boemare, N. Biology, taxonomy, and systematics of Photorhabdus and Xenorhabdus. In Entomopathogenic Nematology; Gaugler, R., Ed.; CABI International: Wallingford, UK, 2002; pp. 35-56. 
3. Snyder, H.; Stock, S.P.; Kim, S.K.; Flores-Lara, Y.; Forst, S. New insights into the colonization and release processes of Xenorhabdus nematophila and the morphology and ultrastructure of the bacterial receptacle of its nematode host, Steinernema carpocapsae. Appl. Environ. Microbiol. 2007, 73, 5338-5346. [CrossRef] [PubMed]

4. Dowds, B.C.A.; Peters, A. Virulence mechanisms. In Entomopathogenic Nematology; Gaugler, R., Ed.; CABI: New York, NY, USA, 2002; pp. 79-98.

5. Lacey, L.A.; Grzywacz, D.; Shapiro-Ilan, D.I.; Frutos, R.; Brownbridge, M.; Goettel, M.S. Insect pathogens as biological control agents: Back to the future. J. Invertebr. Pathol. 2015, 132, 1-41. [CrossRef] [PubMed]

6. Brivio, M.F.; Mastore, M. Nematobacterial complexes and insect hosts: Different weapons for the same war. Insects 2018, 9, 117. [CrossRef] [PubMed]

7. Gaugler, R.; Wang, Y.; Campbell, J.F. Aggressive and evasive behaviors in Popillia japonica (Coleoptera, Scarabaeidae) larvae—defenses against entomopathogenic nematode attack. J. Invertebr. Pathol. 1994, 64, 193-199. [CrossRef]

8. Castillo, J.C.; Reynolds, S.E.; Eleftherianos, I. Insect immune responses to nematode parasites. Trends Parasitol. 2011, 27, 537-547. [CrossRef]

9. Eleftherianos, I.; Shokal, U.; Yadav, S.; Kenney, E.; Maldonado, T. Insect immunity to entomopathogenic nematodes and their mutualistic bacteria. Curr. Top. Microbiol. Immunol. 2017, 402, 123-156.

10. Gillespie, J.P.; Kanost, M.R.; Trenczek, T. Biological mediators of insect immunity. Annu. Rev. Entomol. 1997, 42, 611-643. [CrossRef]

11. Kim, C.H.; Park, J.W.; Ha, N.C.; Kang, H.J.; Lee, B.L. Innate immune response in insects: Recognition of bacterial peptidoglycan and amplification of its recognition signal. BMB Rep. 2008, 41, 93-101. [CrossRef]

12. Nappi, A.J.; Kohler, L.; Mastore, M. Signaling pathways implicated in the cellular innate immune responses of Drosophila. Invertebr. Surv. J. 2004, 1, 5-33.

13. Scherfer, C.; Karlsson, C.; Loseva, O.; Bidla, G.; Goto, A.; Havemann, J.; Dushay, M.S.; Theopold, U. Isolation and Characterization of Hemolymph Clotting Factors in Drosophila melanogaster by a Pullout Method. Curr. Biol. 2004, 14, 625-629. [CrossRef] [PubMed]

14. Dziedzeich, A.; Shivankar, S.; Theopold, U. Drosophila melanogaster Responses against Entomopathogenic Nematodes: Focus on Hemolymph Clots. Insects 2020, 11, 62. [CrossRef] [PubMed]

15. Bulet, P.; Stöcklin, R. Insect antimicrobial peptides: Structures, properties and gene regulation. Protein Pept. Lett. 2005, 12, 3-11. [CrossRef] [PubMed]

16. Strand, M.R. The insect cellular immune response. Insect Sci. 2008, 15, 1-14. [CrossRef]

17. De Lerma Barbaro, A.; Gariboldi, M.B.; Mastore, M.; Brivio, M.F.; Giovannardi, S. In Vivo Effects of A Pro-PO System Inhibitor on the Phagocytosis of Xenorhabdus nematophila in Galleria mellonella Larvae. Insects 2019, 10, 263. [CrossRef]

18. Lemaitre, B.; Hoffmann, J. The host defense of Drosophila melanogaster. Annu. Rev. Immunol. 2007, 25, 697-743. [CrossRef]

19. Letourneau, M.; Lapraz, F.; Sharma, A.; Vanzo, N.; Waltzer, L.; Crozatier, M. Drosophila hematopoiesis under normal conditions and in response to immune stress. FEBS Lett. 2016, 590, 4034-4051. [CrossRef]

20. Rizki, T.; Rizki, R.; Grell, E. A mutant affecting the crystal cells in Drosophila melanogaster. Roux's Arch. Dev. Biol. 1980, 188, 91-99. [CrossRef]

21. Binda-Rossetti, S.; Mastore, M.; Protasoni, M.; Brivio, M.F. Effects of an entomopathogen nematode on the immune response of the insect pest red palm weevil: Focus on the host antimicrobial response. J. Invertebr. Pathol. 2016, 133, 110-119. [CrossRef]

22. Brivio, M.F.; Mastore, M.; Nappi, A.J. A pathogenic parasite interferes with phagocytosis of insect immunocompetent cells. Dev. Comp. Immunol. 2010, 34, 991-998. [CrossRef]

23. Wang, Y.; Gaugler, R. Steinernema glaseri surface coat protein suppresses the immune response of Popillia japonica (Coleoptera: Scarabaeidae) larvae. Biol. Control 1999, 14, 45-50. [CrossRef]

24. Mastore, M.; Brivio, M.F. Cuticular surface lipids are responsible for disguise properties of an entomoparasite against host cellular responses. Dev. Comp. Immunol. 2008, 32, 1050-1062. [CrossRef] [PubMed]

25. Toubarro, D.; Avila, M.M.; Hao, Y.; Balasubramanian, N.; Jing, Y.; Montiel, R.; Faria, T.Q.; Brito, R.M.; Simões, N. A serpin released by an entomopathogen impairs clot formation in insect defense system. PLoS ONE 2013, 8, e69161. [CrossRef] [PubMed] 
26. Mastore, M.; Arizza, V.; Manachini, B.; Brivio, M.F. Modulation of immune responses of Rhynchophorus ferrugineus (Insecta: Coleoptera) induced by the entomopathogenic nematode Steinernema carpocapsae (Nematoda: Rhabditida). Insect Sci. 2015, 22, 748-760. [CrossRef] [PubMed]

27. Brivio, M.F.; Toscano, A.; Pasquale, S.M.; Barbaro, A.D.; Giovannardi, S.; Finzi, G.; Mastore, M. Surface protein components from entomopathogenic nematodes and their symbiotic bacteria: Effects on immune responses of the greater wax moth, Galleria mellonella (Lepidoptera: Pyralidae). Pest Manag. Sci. 2018, 74, 2089-2099. [CrossRef]

28. Park, Y.; Kim, Y. Xenorhabdus nematophilus inhibits p-bromophenacyl bromide (BPB)-sensitive PLA2 of Spodoptera exigua. Arch. Insect Biochem. Physiol. 2003, 54, 134-142. [CrossRef]

29. Walsh, D.B.; Bolda, M.P.; Goodhue, R.E.; Dreves, A.J.; Lee, J.; Bruck, D.J.; Walton, V.M.; O’Neal, S.D.; Zalom, F.G. Drosophila suzukii (Diptera: Drosophilidae): Invasive Pest of Ripening Soft Fruit Expanding its Geographic Range and Damage Potential. J. Integr. Pest Manag. 2011, 2, 1-7. [CrossRef]

30. Haye, T.; Girod, P.; Cuthbertson, A.G.S.; Wang, X.G.; Daane, K.M.; Hoelmer, K.A.; Baroffio, C.; Zhang, J.P.; Desneux, N. Current SWD IPM tactics and their practical implementation in fruit crops across different regions around the world. J. Pest Sci. 2016, 89, 643-651. [CrossRef]

31. Lee, J.C.; Wang, X.; Daane, K.M.; Hoelmer, K.A.; Isaacs, R.; Sial, A.A.; Walton, V.M. Biological control of spotted-wing drosophila—current and pending tactics. J. Integr. Pest Manag. 2019, 10, 13. [CrossRef]

32. Chabert, S.; Allemand, R.; Poyet, M.; Eslin, P.; Gibert, P. Ability of European parasitoids (Hymenoptera) to control a new invasive Asiatic pest, Drosophila suzukii. Biol. Control 2012, 63, 40-47. [CrossRef]

33. Poyet, M.; Havard, S.; Prevost, G.; Chabrerie, O.; Doury, G.; Gibert, P.; Eslin, P. Resistance of Drosophila suzukii to the larval parasitoids Leptopilina heterotoma and Asobara japonica is related to haemocyte load. Physiol. Entomol. 2013, 38, 45-53. [CrossRef]

34. Stacconi, M.V.; Amiresmaeili, N.; Biondi, A.; Carli, C.; Caruso, S.; Dindo, M.L.; Francati, S.; Gottardello, A.; Grassi, A.; Lupi, D.; et al. Host location and dispersal ability of the cosmopolitan parasitoid Trichopria drosophilae released to control the invasive spotted wing Drosophila. Biol. Control 2018, 117, 188-196. [CrossRef]

35. Yousef, M.; Aranda-Valera, E.; Quesada-Moraga, E. Lure-and-infect and lure-and-kill devices based on Metarhizium brunneum for spotted wing Drosophila control. J. Pest Sci. 2018, 91, 227-235. [CrossRef]

36. Garriga, A.; Morton, A.; Garcia-del-Pino, F. Is Drosophila suzukii as susceptible to entomopathogenic nematodes as Drosophila melanogaster? J. Pest Sci. 2018, 91, 789-798. [CrossRef]

37. Garriga, A.; Morton, A.; Ribes, A.; Garcia-del-Pino, F. Soil emergence of Drosophila suzukii adults: A susceptible period for entomopathogenic nematodes infection. J. Pest Sci. 2020, 93, 639-646. [CrossRef]

38. Woodring, J.L.; Kaya, H.K. Steinernematid and heterorhabditid nematodes: A handbook of techniques. South. Coop. Bull. 1998, 331, 1-30.

39. White, G.F. A method for obtaining infective nematode larvae from cultures. Science 1927, 66, $302-303$. [CrossRef]

40. Park, Y.; Kim, Y. Eicosanoids rescue Spodoptera exigua infected with Xenorhabdus nematophilus, the symbiotic bacteria to the entomopathogenic nematode Steinernema carpocapsae. J. Insect Physiol. 2000, 46, 1469-1476. [CrossRef]

41. Mastore, M.; Brivio, M.F. Basic Methods to Evaluate Humoral Immunity Processes in Lepidoptera Larvae. In Immunity in Insects. Springer Protocols Handbooks; Sandrelli, F., Tettamanti, G., Eds.; Humana: New York, NY, USA, 2020; pp. 127-144. [CrossRef]

42. Schägger, H.; Von Jagow, H. Tricine-sodium dodecyl sulfate-polyacrylamide gel electrophoresis for the separation of proteins in the range from 1 to $100 \mathrm{kDa}$. Anal. Biochem. 1987, 166, 368-379. [CrossRef]

43. Arefin, B.; Kucerova, L.; Krautz, R.; Kranenburg, H.; Parvin, F.; Theopold, U. Apoptosis in hemocytes induces a shift in effector mechanisms in the Drosophila immune system and leads to a pro-inflammatory state. PLoS ONE 2015, 10, e0136593. [CrossRef]

44. R Core Team. R: A Language and Environment for Statistical Computing; R Foundation for Statistical Computing: Vienna, Austria, 2017; Available online: http://www.R-project.org/ (accessed on 26 September 2019).

45. Peña, J.M.; Carrillo, M.A.; Hallem, E.A. Variation in the susceptibility of Drosophila to different entomopathogenic nematodes. Infect. Immun. 2015, 83, 1130-1138. [CrossRef] [PubMed]

46. Kim, Y.G.; Shrestha, S.; Song, C.J.; Seo, S.Y. Bacterial metabolites of an entomopathogenic bacterium, Xenorhabdus nematophila, inhibit a catalytic activity of phenoloxidase of the diamondback moth, Plutella xylostella. J. Microbiol. Biotechnol. 2011, 21, 317-322. 
47. Scarpati, M.; Qi, Y.; Govind, S.; Singh, S. A combined computational strategy of sequence and structural analysis predicts the existence of a functional eicosanoid pathway in Drosophila melanogaster. PLoS ONE 2019, 14, e0211897. [CrossRef] [PubMed]

48. Mastore, M.; Quadroni, S.; Toscano, A.; Mottadelli, N.; Brivio, M.F. Susceptibility to entomopathogens and modulation of basal immunity in two insect models at different temperatures. J. Therm. Biol. 2019, 79, 15-23. [CrossRef]

49. Daffre, S.; Kylsten, P.; Samakovlis, C.; Hultmark, D. The lysozyme locus in Drosophila melanogaster: An expanded gene family adapted for expression in the digestive tract. Mol. Gen. Genet. 1994, 242, $152-162$. [CrossRef]

50. Ji, D.; Kim, Y. An entomopathogenic bacterium, Xenorhabdus nematophila, inhibits the expression of an antibacterial peptide, cecropin, of the beet armyworm, Spodoptera exigua. J. Insect Physiol. 2004, 50, 489-496. [CrossRef]

51. Duvic, B.; Jouan, V.; Essa, N.; Girard, P.A.; Pages, S.; Khattar, Z.A.; Volkoff, N.A.; Givaudan, A.; Destoumieux-Garzón, D.; Escoubas, J.M. Cecropins as a marker of Spodoptera frugiperda immunosuppression during entomopathogenic bacterial challenge. J. Insect Physiol. 2012, 58, 881. [CrossRef]

52. Mastore, M.; Binda Rossetti, S.; Giovannardi, S.; Scarì, G.; Brivio, M.F. Inducible factors with antimicrobial activity after immune challenge in the haemolymph of Red Palm Weevil (Insecta). Innate Immun. 2015, 21, 392-405. [CrossRef]

53. McQuade, R.; Stock, S.P. Secretion systems and secreted proteins in gram-negative entomopathogenic bacteria: Their roles in insect virulence and beyond. Insects 2018, 9, 68. [CrossRef]

54. Shrestha, S.; Kim, Y. An entomopathogenic bacterium, Xenorhabdus nematophila, inhibits hemocyte phagocytosis of Spodoptera exigua by inhibiting phospholipase A A $_{2}$ J. Invertebr. Pathol. 2007, 96, 64-70. [CrossRef]

55. Au, C.; Dean, P.; Reynolds, S.E.; Ffrench-Constant, R.H. Effect of the insect pathogenic bacterium Photorhabdus on insect phagocytes. Cell. Microbiol. 2004, 6, 89-95. [CrossRef] [PubMed]

56. Ebrahimi, L.; Niknam, G.; Dunphy, G.B. Hemocyte responses of the Colorado potato beetle, Leptinotarsa decemlineata, and the greater wax moth, Galleria mellonella, to the entomopathogenic nematodes, Steinernema feltiae and Heterorhabditis bacteriophora. J. Insect Sci. 2011, 11, 75. [CrossRef] [PubMed]

57. Dunphy, G.; Webster, J. Partially characterized components of the epicuticle of dauer juvenile Steinernema feltiae and their influence on the hemocyte activity in Galleria mellonella. J. Parasitol. 1987, 73, 584-588. [CrossRef]

58. Brivio, M.F.; Mastore, M.; Moro, M. The role of Steinernema feltiae body-surface lipids in host-parasite immunological interactions. Mol. Biochem. Parasitol. 2004, 135, 111-121. [CrossRef]

59. Kacsoh, B.Z.; Schlenke, T.A. High hemocyte load is associated with increased resistance against parasitoids in Drosophila suzukii, a relative of D. melanogaster. PLoS ONE 2012, 7, e34721. [CrossRef]

60. Balasubramanian, N.; Hao, Y.J.; Toubarro, D.; Nascimento, G.; Simões, N. Purification, biochemical and molecular analysis of a chymotrypsin protease with prophenoloxidase suppression activity from the entomopathogenic nematode Steinernema carpocapsae. Int. J. Parasitol. 2009, 39, 975-984. [CrossRef]

(C) 2020 by the authors. Licensee MDPI, Basel, Switzerland. This article is an open access article distributed under the terms and conditions of the Creative Commons Attribution (CC BY) license (http://creativecommons.org/licenses/by/4.0/). 